\title{
THE LITHOSPHERIC MANTLE BENEATH THE BUFFALO HEAD TERRANE, ALBERTA: XENOLITHS FROM THE BUFFALO HILLS KIMBERLITES
}

\author{
Sonja Aulbach ${ }^{1}$, W.L. Griffin ${ }^{1,2}$, Suzanne Y. O'Reilly ${ }^{1}$ and Tom E. McCandless ${ }^{3}$ \\ ${ }^{1}$ GEMOC ARC National Key Centre, Macquarie University, Australia; ${ }^{2}$ CSIRO Exploration and Mining, North \\ Ryde, Australia; ${ }^{3}$ Ashton Mining Canada Inc., North Vancouver, Canada
}

In areas with thick sedimentary cover and recent glacial deposits, such as the Buffalo Head terrane in northern Alberta, information on the crust and mantle below is often restricted to geophysical data. Fortunately, using these methods, a new kimberlite province (Buffalo Hills kimberlites) was identified in the centre of the Buffalo Head terrane (Carlson et al., 1999), which has opened an opportunity to directly study the lithosphere below by means of xenoliths and xenocrysts transported to the surface. Samples from three kimberlites (K6, K11, K14), erupted at 88-86 Ma (Carlson et al., 1999), were used in a reconnaissance study including acquisition of major-element, trace-element and isotopic data, in order to constrain the paleogeotherm and the stratigraphy of the subcontinental lithospheric mantle (SCLM) beneath this region, and to assess its origin and evolution.

\section{MAJOR AND TRACE ELEMENTS, RE- OS ISOTOPE DATA}

Two major xenolith types are present. The Cr-diopside peridotite series includes spinel lherzolites, a garnetspinel-lherzolite, garnet peridotites with altered orthopyroxene (opx) and a sheared garnet lherzolite. The pyroxenite series includes garnet-free and garnetbearing pyroxenites, one of which has a striking corona structure suggesting exsolution from a very coarsegrained protolith. Peridotitic garnets have $\mathrm{Cr}_{2} \mathrm{O}_{3}-\mathrm{CaO}$ systematics consistent with lherzolite and calcic harzburgite sources. Garnet xenocrysts additionally indicate the presence of wehrlitic. Pyroxenite garnets have $\mathrm{Cr}_{2} \mathrm{O}_{3}$ contents below $1 \mathrm{wt} \%$ and restricted $\mathrm{CaO}$ contents in accord with the buffering effect of coexisting opx. Opx and clinopyroxene (cpx) in many samples show micrometer-scale exsolution of the complementary pyroxene plus or minus spinel. Spinels are extremely heterogeneous, and show secondary overgrowths with increased $\mathrm{TiO}_{2}, \mathrm{Cr}_{2} \mathrm{O}_{3}$ and $\mathrm{Fe}^{3+}$ contents. Chondrite-normalised REE patterns are shown in Fig. 1 and some major and trace element analyses are given in Table 1. Re-Os isotope data were obtained for sulfides in six peridotites using a New Wave LUV266 laser microprobe attached to a $\mathrm{Nu}$ Instruments "NU
Plasma" multicollector ICPMS (Table 2). Samples with negative $\gamma_{O}$ give $\mathrm{T}_{\mathrm{RD}}$ of $0.40 \pm 0.20$ and $1.46 \pm 0.44 \mathrm{Ga}$. One sample with superchondritic ${ }^{187} \mathrm{Os} /{ }^{188} \mathrm{Os}$ gives a model age of $1.73 \pm 0.13 \mathrm{Ga}$ which agrees within error with the model age of $1.89 \pm 0.38 \mathrm{Ga}$ of the sample giving the $1.46 \mathrm{Ga} \mathrm{T}_{\mathrm{RD}}$. The remainder give implausible model ages.

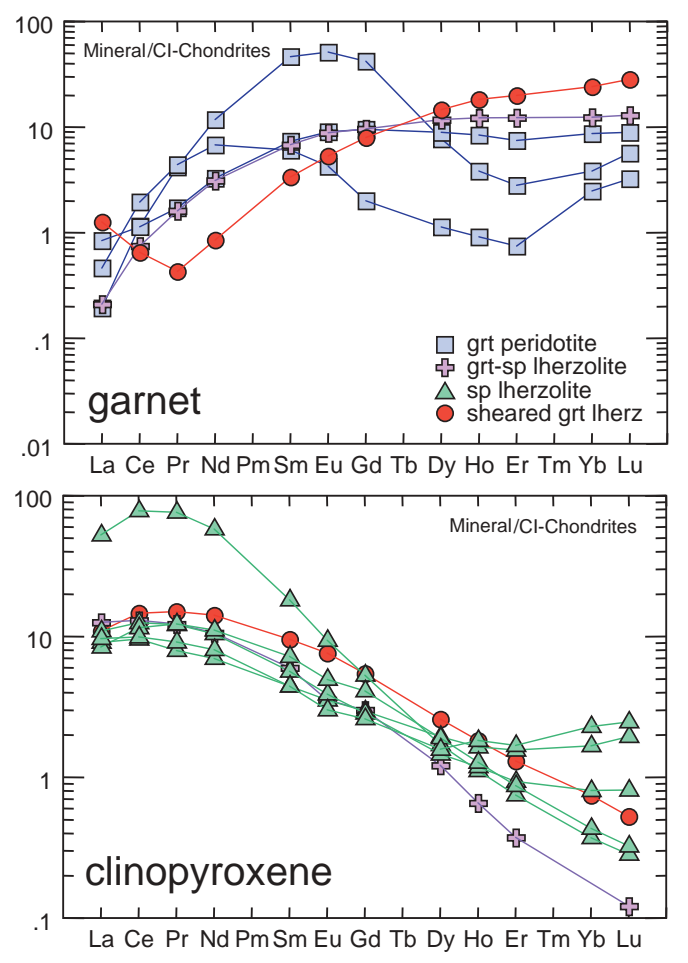

Figure 1 Chondrite-normalised REE patterns of garnet and cpx in peridotites; chondrite of McDonough and Sun (1995)

\section{Table 1: Major and trace-element composition of some peridotite minerals}

\begin{tabular}{|c|c|c|c|c|}
\hline Garnet & k11-3 & k11-5 & k14-1 & k14-3 \\
\hline Type & gt per & gt per & gt lh & gt lh \\
\hline $\mathrm{SiO}_{2}[\mathrm{wt} \%]$ & 42.32 & 41.29 & 42.01 & 41.86 \\
\hline $\mathrm{TiO}_{2}$ & 0.01 & 0.79 & 0.79 & 0.06 \\
\hline $\mathrm{Al}_{2} \mathrm{O}_{3}$ & 21.65 & 17.98 & 19.35 & 21.70 \\
\hline $\mathrm{Cr}_{2} \mathrm{O}_{3}$ & 3.17 & 6.96 & 3.73 & 2.01 \\
\hline $\mathrm{FeO}$ & 7.51 & 7.21 & 8.19 & 9.90 \\
\hline
\end{tabular}




\begin{tabular}{|c|c|c|c|c|c|c|c|c|c|}
\hline $\mathrm{MnO}$ & 0.49 & 0.21 & 0.21 & 0.51 & $\mathrm{Lu}$ & 0.013 & 0.007 & 0.003 & 0.020 \\
\hline $\mathrm{MgO}$ & 20.19 & 21.72 & 20.81 & 18.09 & $\mathrm{Nb}$ & 0.5 & 0.4 & 1.9 & 0.39 \\
\hline $\mathrm{CaO}$ & 5.31 & 4.10 & 4.81 & 5.87 & $\mathrm{Zr}$ & 6 & 5.9 & 5.2 & 8.0 \\
\hline Total & 100.6 & 100.3 & 99.9 & 100.0 & $\mathrm{Hf}$ & 0.35 & 0.30 & 0.33 & 0.29 \\
\hline Mg\# & 82.7 & 84.3 & 81.9 & 76.5 & Th & 0.06 & 0.13 & 0.20 & 0.10 \\
\hline $\mathrm{V}$ [ppm] & 100 & 440 & 270 & 160 & $\mathrm{U}$ & 0.01 & 0.033 & 0.03 & 0.026 \\
\hline $\mathrm{Sc}$ & 330 & 165 & 94 & 140 & $\mathrm{Sr}$ & 152 & 376 & 176 & 77 \\
\hline $\mathrm{Ti}$ & 17.2 & 400 & 5100 & 900 & & & & & \\
\hline $\mathrm{Y}$ & 5.4 & 0.8 & 17.4 & 24 & $\underline{\text { Opx }}$ & $\underline{\text { k14-1 }}$ & k14-2b & k14-3a & k14-6 \\
\hline $\mathrm{La}$ & 0.046 & 0.11 & 0.05 & 0.3 & Type & gt lh & gt lh & $\mathrm{sp} \mathrm{lh}$ & $\mathrm{sp} \mathrm{lh}$ \\
\hline $\mathrm{Ce}$ & 0.71 & 1.2 & 0.46 & 0.4 & $\mathrm{SiO}_{2}[\mathrm{wt} \%]$ & 57.67 & 57.04 & 57.62 & 55.93 \\
\hline $\mathrm{Nd}$ & 5.4 & 3.1 & 1.43 & 0.39 & $\mathrm{Al}_{2} \mathrm{O}_{3}$ & 0.73 & 2.43 & 1.40 & 2.43 \\
\hline $\mathrm{Sm}$ & 6.9 & 0.9 & 1.01 & 0.5 & $\mathrm{Cr}_{2} \mathrm{O}_{3}$ & 0.19 & 0.43 & 0.31 & 0.42 \\
\hline $\mathrm{Eu}$ & 2.9 & 0.24 & 0.5 & 0.3 & $\mathrm{FeO}$ & 5.98 & 5.82 & 5.75 & 5.63 \\
\hline Gd & 8.4 & 0.4 & 1.92 & 1.59 & $\mathrm{MnO}$ & 0.12 & 0.11 & 0.14 & 0.14 \\
\hline Dy & 1.91 & 0.28 & 2.9 & 3.6 & $\mathrm{MgO}$ & 34.15 & 34.68 & 35.22 & 34.31 \\
\hline Но & 0.21 & 0.05 & 0.67 & 1.0 & $\mathrm{CaO}$ & 1.00 & 0.45 & 0.18 & 0.42 \\
\hline $\mathrm{Er}$ & 0.45 & 0.12 & 1.97 & 3.2 & $\mathrm{NiO}$ & 0.13 & $<0.08$ & 0.08 & 0.08 \\
\hline $\mathrm{Yb}$ & 0.62 & 0.4 & 2.0 & 3.9 & Total & 100.3 & 101.1 & 100.7 & 99.4 \\
\hline $\mathrm{Lu}$ & 0.140 & 0.08 & 0.32 & 0.7 & $\mathrm{Mg} \#$ & 91.1 & 91.4 & 91.6 & 91.6 \\
\hline $\mathrm{Nb}$ & 0.32 & 1.09 & 0.59 & 2.2 & & & & & \\
\hline $\mathrm{Zr}$ & 55 & 16 & 58 & 36 & $\underline{\text { Olivine }}$ & k11-3 & k11-5 & k14-1 & k14-3a \\
\hline $\mathrm{Hf}$ & 0.54 & 0.71 & 0.015 & 0.03 & Type & gt per & gt per & gt lh & gt lh \\
\hline Th & 0.011 & 0.08 & 0.015 & 0.03 & $\mathrm{SiO}_{2}[\mathrm{wt} \%]$ & 41.67 & 41.04 & 40.86 & 40.89 \\
\hline $\mathrm{U}$ & $<0.05$ & 0.09 & $<0.1$ & 0.2 & $\mathrm{FeO}$ & 7.05 & 8.29 & 9.91 & 8.65 \\
\hline $\mathrm{Sr}$ & 0.5 & $<1.8$ & 0.9 & 0.4 & $\mathrm{MnO}$ & 0.10 & 0.12 & 0.11 & 0.11 \\
\hline & & & & & $\mathrm{MgO}$ & 51.76 & 50.92 & 49.09 & 50.56 \\
\hline$\underline{\text { Cpx }}$ & $\underline{\text { k14-1 }}$ & k14-2b & k14-3a & k14-6 & $\mathrm{NiO}$ & 0.39 & 0.36 & 0.39 & 0.37 \\
\hline Type & gt lh & gt lh & $\mathrm{sp} \mathrm{lh}$ & $\mathrm{sp} \mathrm{lh}$ & Total & 101.0 & 100.7 & 100.4 & 100.6 \\
\hline $\mathrm{SiO}_{2}[\mathrm{wt} \%$ & ] 55.01 & 54.29 & 54.64 & 52.94 & Mg\# & 92.9 & 91.6 & 89.8 & 91.2 \\
\hline $\mathrm{TiO}_{2}$ & 0.21 & 0.11 & 0.11 & $<0.06$ & Mode & 85 & 78 & 78 & 43 \\
\hline $\mathrm{Al}_{2} \mathrm{O}_{3}$ & 1.79 & 2.99 & 1.66 & 2.63 & & & & & \\
\hline $\mathrm{Cr}_{2} \mathrm{O}_{3}$ & 1.01 & 0.99 & 0.7 & 0.91 & \multirow{2}{*}{\multicolumn{5}{|c|}{ Table 2: Re-Os isotope data }} \\
\hline $\mathrm{FeO}$ & 3.80 & 1.59 & 1.75 & 1.78 & & & & & \\
\hline $\mathrm{MnO}$ & 0.1 & $<0.09$ & $<0.09$ & $<0.09$ & & & K6-1 & k14-3a & K14-5b \\
\hline $\mathrm{MgO}$ & 18.62 & 16.09 & 17.3 & 16.52 & \multicolumn{2}{|l|}{ Type } & gt lh & gt lh & gt lh \\
\hline $\mathrm{CaO}$ & 17.46 & 23.51 & 23.62 & 23.79 & \multicolumn{2}{|l|}{${ }^{187} \mathrm{Re} /{ }^{188} \mathrm{Os}$} & 0.540 & 0.513 & 10.71 \\
\hline $\mathrm{Na} 2 \mathrm{O}$ & 1.61 & 1.04 & 0.65 & 0.55 & & 0.024 & 0.026 & 0.38 \\
\hline Total & 99.6 & 100.7 & 100.4 & 99.1 & \multicolumn{2}{|l|}{${ }^{187} \mathrm{Os} /{ }^{188} \mathrm{Os}$} & 0.1680 & 0.1809 & 0.430 \\
\hline $\mathrm{Mg} \#$ & 89.7 & 94.7 & 94.6 & 94.3 & \multicolumn{2}{|l|}{2 se } & 0.0012 & 0.0027 & 0.016 \\
\hline $\mathrm{V}$ [ppm] & 200 & 250 & 180 & 200 & \multicolumn{2}{|l|}{$\gamma \mathrm{Os}$} & 32.2 & 42.4 & 240 \\
\hline $\mathrm{Sc}$ & 12.3 & 47 & 30 & 51 & \multicolumn{2}{|l|}{$\mathrm{T}_{\mathrm{RD}}$} & na & na & na \\
\hline $\mathrm{Ti}$ & 1280 & 610 & 800 & 300 & \multirow{3}{*}{\multicolumn{2}{|c|}{$\mathrm{T}_{\text {CHUR }}$}} & 15492 & 23549 & 1737 \\
\hline $\mathrm{Y}$ & 2.4 & 1.5 & 0.9 & 1.6 & & & & & \\
\hline $\mathrm{La}$ & 2.6 & 12.5 & 3 & 2.6 & & & $\underline{\text { k14-5d }}$ & k14-6 & k14-7a \\
\hline $\mathrm{Ce}$ & 9 & 48 & 8 & 7.7 & \multirow{2}{*}{\multicolumn{2}{|c|}{$\begin{array}{l}\text { Type } \\
{ }^{187} \mathrm{Re} /{ }^{188} \mathrm{Os}\end{array}$}} & gt lh & gt lh & gt lh \\
\hline $\mathrm{Nd}$ & 6.5 & 26.6 & 4.87 & 4.8 & & & 0.0938 & 1.220 & 0.5471 \\
\hline $\mathrm{Sm}$ & 1.42 & 2.7 & 0.89 & 0.84 & \multicolumn{2}{|l|}{$2 \mathrm{se}$} & 0.0024 & 0.032 & 0.0048 \\
\hline $\mathrm{Eu}$ & 0.43 & 0.53 & 0.2 & 0.22 & \multicolumn{2}{|l|}{${ }^{187} \mathrm{Os} /{ }^{188} \mathrm{Os}$} & 0.1172 & 2.4000 & 0.1244 \\
\hline Gd & 1.09 & 1.06 & 0.6 & 0.57 & \multicolumn{2}{|l|}{$2 \mathrm{se}$} & 0.0026 & 0.0051 & 0.0012 \\
\hline Dy & 0.64 & 0.42 & 0.3 & 0.36 & \multicolumn{2}{|l|}{$\gamma \mathrm{Os}$} & -7.7 & 1789 & -2.12 \\
\hline Но & 0.10 & 0.061 & 0.036 & 0.065 & \multicolumn{2}{|l|}{$\mathrm{T}_{\mathrm{RD}}$} & 1455 & na & 402 \\
\hline $\mathrm{Er}$ & 0.21 & 0.12 & 0.06 & 0.15 & \multirow{2}{*}{\multicolumn{2}{|c|}{$\mathrm{T}_{\mathrm{CHUR}}$}} & 1893 & 79707 & -1114 \\
\hline $\mathrm{Yb}$ & 0.12 & 0.06 & $<0.02$ & 0.13 & & & & & \\
\hline
\end{tabular}




\section{LITHOSPHERE STRUCTURE}

Iterative calculation of $T_{B K N}$ versus $P_{B K N}$ (Brey and Köhler, 1990) for a sheared lherzolite xenolith gives the highest temperature and pressure of all xenoliths $\left(1325^{\circ}\right.$ C, $66 \mathrm{kbar}$ ), equivalent to a 'cool' $42 \mathrm{~mW} / \mathrm{m}^{2}$ geotherm. This is similar to the present-day heatflow in regions of ancient lithosphere stabilisation. The garnet-spinel lherzolite gives $735^{\circ} \mathrm{C}$ and $17 \mathrm{kbar}$ for the same calculation. A preliminary stratigraphy of the SCLM beneath the Buffalo Head Terrane is derived by comparing the relative amount of rock-types in different temperature intervals (Fig. 2). Low-Cr lithologies are restricted to the shallow mantle and harzburgite with Ca-saturated garnet is concentrated in a layer between $\sim 1000-1200^{\circ} \mathrm{C}$ (Fig. 2). The persistence of spinel lherzolites to temperatures above the spinel-garnet transition constrained by garnet-spinel lherzolite may be due to their relatively $\mathrm{Cr}$-rich character. The absence of non-sheared garnet lherzolites in the xenolith suite contrasts with the abundance of lherzolitic garnet xenocrysts and may indicate that this rock type was preferentially comminuted during entrainment in the kimberlite.

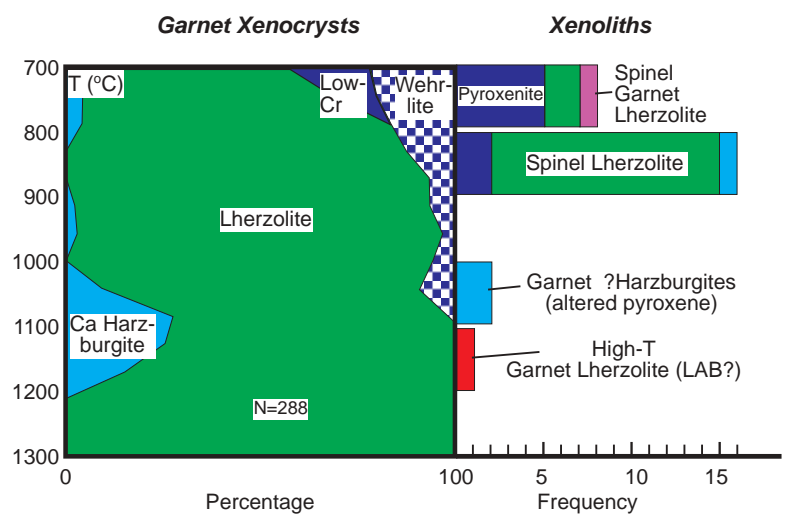

Figure 2 Preliminary lithosphere structure beneath the Buffalo Head terrane, from diagrams of lithologies plotted against equilibration temperatures of xenocrysts (left) and xenoliths (right) using $\mathrm{T}_{\mathrm{Ni} \text {-in-grt }}$ (Ryan et al., 1996) for garnet from heavy mineral concentrate and a combination of $\mathrm{T}_{\text {Ow79, }}$, $\mathrm{T}_{\mathrm{Krogh}}, \quad \mathrm{T}_{\mathrm{BKN}}$ and $\mathrm{T}_{\mathrm{WES} 91}$ and for xenoliths at a nominal pressure of 40 kbar (O'Neill and Wood, 1979; Krogh, 1988; Brey and Köhler, 1990; Witt-Eickschen and Seck, 1991)

The high temperature and pressure obtained for the sheared lherzolite combined with its microstructure and enrichment in basaltic components suggest that it was derived from close to the lithosphere-asthenosphere boundary (LAB) (Smith and Boyd, 1987). It constrains the minimum depth of the SCLM beneath the Buffalo Head Terrane to $180 \mathrm{~km}$.

\section{MELTING}

Most samples from Alberta have $\mathrm{FeO}$ relative to $\mathrm{Al}_{2} \mathrm{O}_{3}$ and $\mathrm{MgO}$ contents similar to experimental melting residues of pyrolite after a loss of between $20-40 \%$ partial melt at pressures between 10 and 40 kbar (Walter, 1999). The same is true for $\mathrm{FeO}$ relative to $\mathrm{SiO}_{2}$ contents, with the exception that one sample is similar to the pyrolite starting composition in the melting experiments. Three samples have high opx/ol similar to peridotites from Kaapvaal and to a lesser extent Siberia, but at higher $\mathrm{FeO}$ contents. In a diagram of modal olivine against olivine Mg-number, most samples plot in the Proterozoic field, while other samples lie on the oceanic trend, having both high $\mathrm{Mg}$ numbers and modal olivine content (Fig. 3).

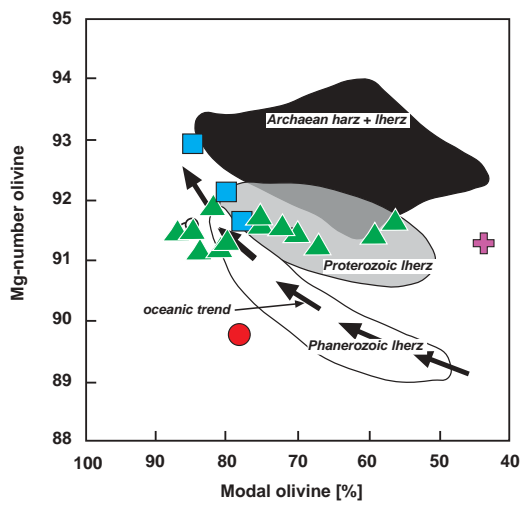

Figure 3 Diagram after Boyd (1989); fields from Pearson et al. (1999). Symbols as in Figure 1

\section{METASOMATISM}

$\mathrm{Zr}$ against $\mathrm{Y}$ abundances, used to distinguish undepleted and depleted garnets from meltmetasomatised and low-temperature (phlogopite) metasomatised garnets (Griffin et al., 1999), show that garnet from the high-temperature sheared lherzolite, from the garnet-spinel lherzolite and garnet from two of the peridotites with altered opx have been meltmetasomatised, consistent with sinusoidal or LREEenriched REE-patterns. Garnet in the third sample with altered opx is melt-depleted and has a strongly LREEdepleted REE pattern. The garnet-spinel peridotite contains numerous grains of pentlandite. Sulfides were identified in 14 samples and are commonly pentlandite which is usually indicative of a metasomatic origin (Alard et al., 2000). This indicates that melt metasomatism was accompanied by an influx of sulfur. A metasomatic origin is consistent with the mostly implausible Re-Os model ages, which indicate 
disturbance of the Re-Os budget, and calls into question the validity of plausible model ages obtained for some of the samples. Reaction with carbonatitic melts and formation of cpx at the expense of opx (Yaxley et al., 1991) may be indicated by the occurrence of wehrlitic garnet xenocrysts derived from the shallower lithosphere (Fig. 2)

\section{A PRECURSORY HEATING AND METASOMATIC EVENT}

Exsolution microstructures and zoning are indicative of incomplete sub-solidus re-equilibration (e.g., Field and Haggerty, 1994). It would therefore appear that the ubiquitous exsolution of complementary pyroxene from cpx and opx in spinel lherzolites records cooling, either during uplift of the mantle volume they resided in, or after a thermal pulse, maybe related to a passing melt, (e.g., Griffin et al., 1987). Evidence for interaction with the host kimberlite itself is restricted to grain boundaries (formation of secondary phlogopite and sulfide), and calculated melts in equilibrium with garnet or cpx do not resemble those of kimberlites. The heterogeneity of most spinels in peridotites from Buffalo Hills, with distinct $\mathrm{TiO}_{2}, \mathrm{Cr}_{2} \mathrm{O}_{3}$ and $\mathrm{Fe}^{3+}$-rich overgrowths could be a young feature and may indicate interaction with an oxidised silicate melt shortly before entrainment in the kimberlite. The exsolution microstructures could have resulted from cooling to the geotherm subsequent to this event. However, storage of these samples at low temperatures may have prevented equilibration for substantial lengths of time and the disequilibrium features may therefore not constrain the timing of the disturbance.

\section{REWORKED ARCHAEAN MANTLE?}

Several features of the samples suggest the presence of Archaean mantle beneath the Buffalo Head Terrane. The sinusoidal trace element patterns of two garnet peridotites resemble those of garnet inclusions in diamond occurring in cratonic, i.e., Archaean areas of the world, and diamonds have been recovered from the host kimberlites. Also, some peridotites plot near the field of Archaean peridotites in the plot of modal olivine against Mg-number of olivine (Fig. 3). U-Pb ages obtained for basement rocks of the Buffalo Head terrane range between 2.32-2.0 Ga, but have upper intercepts suggesting Archaean inheritance (Thériault and Ross, 1991). This suggests an older component is present and that crust-mantle differentiation took place in the Archaean. Ross and Eaton (2002) suggest that the
Buffalo Head terrane represents a collage of Paleoproterozoic crust formed on an Archaean microcontinent. There is evidence for metasomatism by both silicate melts and carbonatitic melts in many peridotites and garnet xenocrysts, accompanied by influx of sulfur and any unambiguous Archaean signatures may have been obliterated during these events.

Reworking may have occurred in the context of Proterozoic crust formation at $2.32-2.0 \mathrm{Ga}$ in the Buffalo Head terrane, which involved minimal recycling of crust and represents mostly involvement of juvenile material. Rifting between the Buffalo Head terrane and the adjacent Rae Province and possible oceanic crust formation at $2.4-2.3 \mathrm{Ga}$ is indicated by the similarity of ages and $\mathrm{Nd}$ isotope systematics, and the occurrence of mafic to ultramafic rocks in the contact (Bostock and van Breemen, 1994). Reworking during rifting could explain the similarity with regard to major element contents of peridotites from the Buffalo Hills kimberlites to those from Tanzania in the East African Rift (Lee and Rudnick, 1999). There, asthenospherelithosphere interaction has lead to strong mantle modification, including carbonatite metasomatism that led to formation of wehrlite (Rudnick et al., 1993), also present beneath the Buffalo Head terrane. 2.0-1.9 Ga subduction away from the Buffalo Head Terrane and collision with the Rae Province (Ross et al., 1991) probably had no impact on the Buffalo Head mantle.

The sheet-like mafic sills of the Winagami reflection sequence, constrained to between 1.89 and $1.76 \mathrm{Ga}$ in age, in the core of the Buffalo Head terrane may be the magmatic expression of brittle indentation of the Rae Province to the east of the Buffalo Head terrane by the Archaean Slave province to the north (Ross and Eaton, 1997, and references therein). The emplacement of these mafic sills and the event that caused the magmatism may have also affected the underlying lithospheric mantle. 1.89 and $1.74 \mathrm{Ga}$ model ages on sulfides in two peridotites may date asthenospheric mantle melts associated with this event. However, considering the evidence for influx of sulfur during metasomatism in other peridotites, these sulfides may also represent mixtures of more ancient sulfides with metasomatic sulfides, in which case they carry no meaningful age information. Pyroxenites recovered from the Buffalo Hills kimberlites are restricted to the shallow lithosphere and may have crystallised during the underplating of mafic melts recorded in the Winagami reflection sequence. 


\section{REFERENCES}

Alard, O., Griffin, W.L., Lorand, J.P., Jackson, S.E., O'Reilly, S.Y., 2000. Non-chondritic distribution of the highly siderophile elements in mantle sulfides. Nature 407, 891-894.

Bostock, H., van Breemen, O., 1994. Ages of detritial and metamorphic zircons and monazites from a preTaltson magmatic zone basin at the western margin of Rae Province. Can. J. Earth Sci. 31, 1353-1364.

Boyd, F.R., 1989. Compositional distinction between oceanic and cratonic lithosphere. Earth Planet. Sci. Lett. 96, $15-26$.

Brey, G.P., Köhler, T., 1990. Geothermobarometry in fourphase lherzolites II. New thermobarometers, and practical assessment of existing thermobarometers. J. Petrol. 31, 1353-1378.

Carlson, J.A., Kirkley, M.B., Thomas, E.M., Hillier, W.D., 1999. Recent Canadian Kimberlite Discoveries. In: Gurney, J.J., Gurney, J.L., Pascoe, M.D., Richardson, S.H. (Eds.), Proc. 7th Int. Kimb. Conf., Red Roof Design cc, Cape Town, pp. 81-89.

Field, S., Haggerty, S., 1994. Symplectites in upper mantle peridotites: development and implications for the growth of subsolidus garnet, pyroxene and spinel. Contrib. Mineral. Petrol. 118, 138-156.

Griffin, W.L., Smith, D., Boyd, F.R., 1987. Trace-element zoning in garnets from sheared mantle xenoliths. Geochim. Cosmochim. Acta 53, 561-567.

Griffin, W.L., Fisher, N.I., Friedman, J.H., Ryan, C.G., O'Reilly, S.Y., 1999. Cr-pyrope garnets in the lithospheric mantle I. Compositional systematics and relations to tectonic setting. J. Petrol. 40, 679-705.

Krogh, E., 1988. The garnet-clinopyroxene iron-magnesium geothermometer - a reinterpretation of existing experimental data. Contrib. Mineral. Petrol. 99, 44-48.

Lee, C.-T., Rudnick, R.L., 1999. Compositionally stratified cratonic lithosphere: petrology and geochemistry of peridotite xenoliths from the Labait tuff cone, Tanzania. In: Gurney, J.J., Gurney, J.L., Pascoe, M.D., Richardson, S.H. (Eds.), Proc. 7th Int. Kimb. Conf., Red Roof Design cc, Cape Town, pp. 503-521.

McDonough, W.F., Sun, S.-S., 1995. The composition of the Earth. Chem. Geol. 120, 223-253.

O'Neill, H., Wood, B., 1979. An experimental study of the iron-magnesium partitioning between garnet and olivine and its calibration as a geothermometer. Contrib. Mineral. Petrol. 70, 59-70.

Pearson, N.J., Griffin, W.L., Doyle, B.J., O'Reilly, S.Y., van Achterbergh, E., Kivi, K., 1999. Xenoliths from kimberlite pipes of the Lac de Gras area, Slave
Craton, Canada. In: Gurney, J.J., Gurney, J.L., Pascoe, M.D., Richardson, S.H. (Eds.), Proc. 7th Int. Kimb. Conf., Red Roof Design cc, Cape Town, pp. 644-658.

Ross, G.M., Eaton, D.W., 1997. Winagami reflection sequence: seismic evidence for post-collisional magmatism in the Proterozoic of western Canada. Geology 25, 199-202.

Ross, G.M., Parrish, R.R., Villeneuve, M.E., Bowring, S.A., 1991. Geophysics and geochronology of the crystalline basement of the Alberta Basin, western Canada. Can. J. Earth Sci. 28, 512-522.

Ross, G.M., Eaton, D.W., 2002. Proterozoic tectonic accretion and growth of western Laurentia: results from Lithoprobe studies in northern Alberta. Can. J. Earth Sci. 39, 313-329.

Rudnick, R.L., McDonough, W.F., Chappell, B.W., 1993. Carbonatite metasomatism in the northern Tanzanian mantle: petrographic and geochemical characteristics. Earth Planet. Sci. Lett. 114, 463-475.

Ryan, C.G., Griffin, W.L., Pearson, N.J., 1996. Garnet geotherms - pressure-temperature data from $\mathrm{Cr}$ pyrope garnet xenocrysts in volcanic rocks. J Geophys Res, 101, B3: 5611-5625.

Smith, D., 1999. Temperatures and pressures of mineral equilibration in peridotite xenoliths: Review, discussion, and implications. In: Fei, Y., Bertka, C.M., Mysen, B.O. (Eds.), Mantle Petrology: Field Observations and High Pressure Experimentation, Geochem.Soc., Spec. Publ. No. 6.

Smith, D., Boyd, F.R., 1987. Compositional heterogeneities in a high-temperature lherzolite nodule and implications for mantle processes. In: Nixon, P.H. (Ed.), Mantle Xenoliths. John Wiley and Sons, New York, pp. 551561.

Thériault, R.J., Ross, G.M., 1991. Nd isotopic evidence for crustal recycling in the ca. 2.0 Ga subsurface of western Canada. Can. J. Earth Sci. 28: 1149-1157.

Walter, M.J., 1999. Melting residues of fertile peridotite and the origin of cratonic lithosphere. In: Fei, Y., Bertka, C.M., Mysen, B.O. (Eds.), Mantle Petrology: Field Observation and High Pressure Experimentation. The Geochem. Soc. Spec. Publ., pp. 225-239.

Witt-Eickschen, G., Seck, H., 1991. Solubility of Ca and Al in orthopyroxene from spinel peridotite: an improved version of an empirical geothermometer. Contrib. Mineral. Petrol. 106, 431439.

Yaxley, G.M., Crawford, A.J., Green, D.H., 1991. Evidence for carbonatitic metasomatism in spinel peridotite xenoliths from western Victoria, Australia. Earth Planet. Sci. Lett. 107, 305-317.

Contact: S. Aulbach, GEMOC, Macquarie University 2109, Australia (www.es.mq.edu.au/GEMOC/), E-mail: saulb001@laurel.ocs.mq.edu.au 